\title{
PROSES PERGANTIAAN XADAN PADA UMA LULIK DI DESA LOROTOLUS KABUPATEN MALAKA
}

\author{
Pura Tanya \\ Program Studi Arsitektur, Fakultas Teknik, Universites Dwijendra \\ umbupura4@gmail.com
}

Arya Bagus Mahadwijati Wijaatmaja, S.T., M.T.

Program Studi Arsitektur, Fakultas Teknik, Universites Dwijendra aku@aryabagus.com

\begin{abstract}
Abstrak
Rumah adat merupakan bangunan yang di rancang dan memiliki ciri khas tersendiri dan memiliki gaya arsitektur yang menyusuaikan dengan kebudayaan dan adat istiadat daerah setempat. Apa itu Xadan, Apa makna Xadan bagi masyarakat suku suhi, Bagaimanakah proses pergantiaan Xadan pada uma lulik. Xadan merupakan tempat sacral bagi masyarakat Suku Suhi karea mengandung unsur nilai-nilai spiritual yang sangat tinggi.Masyarakat suku Suhi sangat menghormati para leluhurnya sehingga selalu melaksanakan ritual-ritual sebagai bukti perwujutan sikap menghormati bagi para leluhurnya. Xadan merupakan tempat sesajian bagi para leluhur yang di pakai sewaktu-waktu pada saat upacara untuk mendapatkan ilmu kekebalan tubuh.
\end{abstract}

Kata kunci: Proses Pergantiaan Xadan pada Uma Lulik

\section{Abstract}

A traditional house is a building that is designed and has its own characteristics and has an architectural style that adapts to the local culture and customs. What is Xadan, What is the meaning of Xadan for the people of the Suhi tribe, What is the process of replacing Xadan with the uma lulik. Xadan is a sacred place for the people of the Suhi tribe because it contains elements of very high spiritual values. The Suhi tribe people really respect their ancestors so they always carry out rituals as evidence of honoring their respect for their ancestors. Xadan is a place of offerings for ancestors that are used occasionally during ceremonies to gain immune knowledge.

Key words: Xadan's replacement process at Uma Lulik

\section{PENDAHULUAN}

Rumah adat merupakan bangunan yang di rancang dan memiliki ciri khas tersendiri dan memiliki gaya arsitektur yang menyusuaikan dengan kebudayaan dan adat istiadat daerah setempat. Rumah adat merupakan salah satu unsur kebudayaan yang sangat tinggi nilainya dan perlu di pertahankan atau di lestarikan dalam satu suku tertentu, Keberagaman adat istiadat di Indonesia sangat beragam dan memiliki arti tersendiri yang di wariskan dari leluhur. Seiring berjalannya waktu dimana saat ini begitu banyaknya rumah adat atau rumah tradisional yang mengalami perubahan yang sangat singnifikan dimana yang semula rumah adat menggunakan bahan-bahan tradisional berubah menggunakan bahan modern karena menganggap bahan modern mudah atau gampang di dapatkan sehingga dimana saat ini rumah tradisional atau rumah adat hampir punah.

Uma lulik (rumah pemali) merupakan rumah adat dari Masyarakat suku Suhi di Desa Lorotolus Kabupaten Malaka- NTT yang mempunyai nilai sakral dan berfungsi sebagai tempat untuk pemujaan arwah nenek moyang ,upacara adat lainnya misalkan seperti upacara rutinitas pergantiaan Xadan tiga tahun sekali. Pada upacara ini bahan-bahan yang di pakai untuk Xadan yang baru aka menggunakan bahan tradisional misalkan untuk mengikat tidak menggunakan paku tapi menggunakan kayu lilit yang masyarakat setempat menyebutnya $a i$ ktalik upacara pergantian Xadan pada Uma Lulik juga sangat penting bagi masyarakat Suku Suhi sebab selain sebagai penghomatan bagi para leluhur upacara ini juga sangat bermemfaat bagi kehidupan masyarakat suku suhi karena masyarat suku suhi meyakikini bahwa dengan 
adanya upacara ini maka mereka akan mempunyai kekebalan tubuh dari senjata tajam atau senjata api. Penelitiaan ini bertujuaan untuk memberikan edukasi kepada para generasi penerus suku suhi agar memahami memfaat xadan pada Uma Lulik sebagai salah satu kebudayaan daerah setempat yang perlu di lestarikan karena mengandung nilai histori dan sakral.

a) Rumusan Masalah diatas adalah sebagai berikut (1) Apa itu Xadan? (2). Apa makna Xadan bagi masyarakat suku suhi? (3). Bagaimanakah proses pergantiaan Xadan pada uma lulik?

b) Tujuan Penelitian diatas adalah (1) Untuk mengetahui apa itu Xadan (2) Untuk mengetahui makna Xadan bagi masyarakat suku suhi (3)Untuk mengetahui proses pergantiaan Xadan pada uma lulik

c) Adapun Manfaat Penelitian diatas adalah sebagai beriikut (1) Untuk Masyarakat Sebagai landasan agar masyarakat suku Suhi mengetahui adat istiadat dan dapat melestarikannya serta menjadi alat pemersatu masyarakat suku Suhi. (2) Untuk Mahasiswa sebagai bahan untuk memperkaya pengetahuan mahasiswa tentang rumah rumah adat di Indonesia yang penuh dengan keberagaman

d) Batasan Masalah judul yang dikajian agar tidak terlalu melebar jauh dari tugas penelitian ini, penulis hanya membatasi pokok pembahasan meliputi bangaimanakah pergantiaan Xadan yang lama ke yang baru.

\section{METODE PENELITIAAN}

Metode yang di pakai untuk penelitiaan ini yaitu menggunakan metode Kualitatif Menurut Sugiyono (2014: 9), penelitian kualitatif berlandaskan pada realitas atau fakta dari gejala-gejala yang ada dilapangan. Penelitian ini sangat sesuai dengan topik yang diangkat karena keberadaan rumah adat Uma Lulik merupakan suatu hal yang nyata yang terjadi di kampung Wanibesak Khususnya suku Suhi.

a. Lokasi Penelitian

Penelitian dilakukan di kampung kampung Wanibesak, Desa Lorotolus, kabupaten

Malaka, Kupang, Nusa Tenggara Timur

b. Rancangan Penelitian

Menetukan topik yang akan di lakukan penilitian, Memfokuskan masalah, Pengumpulan

data, Menganalisis dan mengolah data, Mengkomunikasikan hasil penilitian

c. Prosedur Penelitian

Penilitian di tujukan kepada kepala suku rumah adat Uma Lulik sebagai nara sumber utama dalam penilitian ini

d. Jenis Sumber Data

Jenis sumber data yang digunakan adalah data primer (data yang diperoleh secara langsung dari lapangan) yang berupa wawancara.

e. Teknik Pengumpulan Data

f. Observasi partisipatif

Menurut Sugiyono (2014: 227), obsevasi partisipatif adalah pengamatan dan pencatatan yang sistematis terhadap fenomena yang diteliti dimana peneliti juga berpartisipasi dalam kegiatan keseharian dari individu yang diteliti.

1. Wawancara

Wawancara merupakan kegiatan Tanya jawab antara dua orang atau lebih dari secara langsung (Usman, 2014: 55). Pada bagian wawancara ini peneliti menggunakan pedoman wawancara agar pertanyaan yang diajukan tidak keluar dari topik yang dibicarakan.

2. Dokumentasi 
Dokumentasi merupakan catatan peristiwa berupa gambar, tulisan,rekaman, dan karya monumental (Sugiyono, 2014: 240). Data dokumentasi biasanya sebagai data penunjang agar data hasil wawancara dan observasi lebih kredibel.

3. Teknik Analisis Data

\section{a. Reduksi data}

Dalam tahapan ini, peneliti melakukan pengumpulan data di lapangan melalui observasi, wawancara, dan dokumentasi. Untuk mendapat data-data yang mengungkap tentang rumah adat Uma Lulik (Rumah Pemali) di Lorotolus

b. Penyajian Data

Setelah merangkum dan mencari hal-hal pokok dari data yang diperoleh dari lapangan, peneliti menyajikan data yang sudah dirangkum dalam sebuah tulisan yang sifatnya masih sementara karena akan disempurnakan lagi seiring dengan temuan data yang baru baik dari lapangan maupun dari hasil studi pustaka.

\section{HASIL DAN PEMBAHASAN}

Xadan merupakan tempat yang suci atau tempat yang sakral bagi masyarakat suku Suhi di wanibesak Xadan biasanya di pakai atau digunakan oleh masyarakat setempat atau suku Suhi untuk melakukan kegiatan ritual adat atau persembahan berupa 1 ekor ayam jantan merah bagi para leluhur untuk memperoleh atau mendapatkan ilmu yang di inginkan yaitu ilmu kekebalan tubuh atau mendapat perlindungan diri dari leluhur karena masyarakat setempat menyakini dengan memiliki ilmu kekebalan tubuh masyarakat setempat menyakini akan memeliki manfaat tersendiri kerena ilmu kekebalan tubuh biasanya di gunakan oleh para leluhur atau para pendekar guna untuk menambah kemampuaan atau keterampilan dalam ahli bela diri atau perlindungan diri lawan atau musuh.

Perlindungan yang di maksud misalkan ilmu kekebalan tubuh terhadap senjata tajam maupun senjata api dan lainya. Sebelum upacara pergantiaan Xadan di lakukan akan terlebih dahulu di laksanakan musuwarah untuk menentukan kapan waktunya upaca di lakukan maka akan di lakukan tahap persiapan atau tahap perencenaan yaitu di mulai dari musyawarah antara kepala suku dan warga setempat untuk menentukah hari baik atau masyrakat setempat menyebutnya dengan nama Tur Hamutuk (hari baik). setelah tur hamutuk atau tahap perencanaan selesai maka para wanita akan mulai mempersiapkan bahan-bahan untuk keperluaan upacara seperti mempersiapkan padi merah setelah mempersiapkan maka mulailah para wanita menumbuk padi merah atau fai hare mean dengan menggunakan alat tradisional berupa lesung yang biasanya di gunakan dari turun temurun selama tiga hari berturut-turut sebagai bahan untuk kegiatan upacara bagi para leluhur atau nenek moyang untuk meminta restu untuk memperoleh ilmu kekebalan tubuh sebagai ilmu untuk perlindungi diri,dan melindungi keluarga bahkan tidak jarang pula ilmu biasanya di gunakan untuk menjaga kampung dari orang-orang luar yang mau merencanakan kejahatan kerena sering terjadi seperti hal pencurian atau karena terjadinya perselisihan antara kedua bela pihak. 


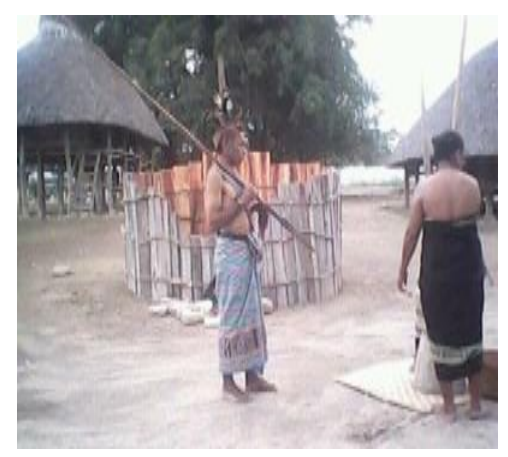

Gambar 1. Upacara Fai Hare Mean Sumber: Tanya, 2019

Sebelum upacara di mulai maka para lelaki akan pergi ke hutan untuk mencari bahan-bahan untuk keperluan proses pembuatan Xadan seperti halnya bahan kayu, tali sebagai bahan untuk proses menggantikan Xadan yang lama yang akan di gantikan dengan Xadan yang baru. Kayu - kayu yang digunakan juga merupakan kayu - kayu pilihan yang berdasarkan persetujuan dari kepala suku setelah memper oleh kayu dan bahan-bahan yang di butuhkan maka masyarakat dan kepala suku akan membawa kayu tersebut ke kampung ditenpat untuk proses pembuatan Xadan.

Adapun tahap untuk proses pembuatan Xadan yang biasanya di awali dengan dengan membuat bentuk Xadan sesuai dengan bentuk yaitu berbentuk bundar atau lingkaran karena bentuk ini merupakan warisan dari leluhur lalu atau turun- temurun setelah bentuk atau pola selesai di buat maka mulailah mempersiapkan kayu yang di butuhkan untuk proses pembuatan Xadan sesuai dengan bentuk dan dimensi yang di inginkan. Dalam proses pembuatan Xadan atau pergantian Xadan para lelaki yang ikut dalam pembuatan Xadan tidak sembarang memakai pakaian akan tetapi para lelaki yang mengikuti proses pergantian Xadan harus mengikuti cara dari para nenek moyang secara turun-temurun yaitu para lelaki tiadak di perbolehkan untuk memakai baju selama proses pembuatan Xadan akan tetapi hanya di perbolehkan memakai sarung saja.Karena jika memakai baju saat pembuatan Xadan di anggap melanggar adat istiadat dari para leluhur karena para leluhur atau masyarakat setempat menganggap bahwa dengan tidak memakai baju melambangkan seorang satria,atau sebagai symbol kejantanan masyarakat setempat menyebutnya MANU AMA

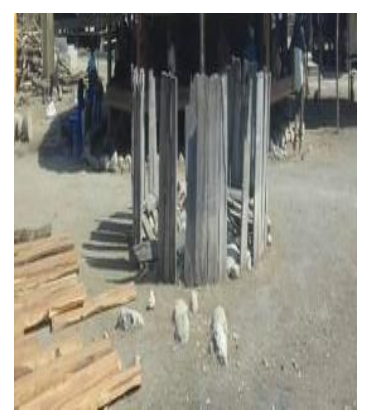

Gambar 2. Xadan yang lama Sumber : Tanya 2019

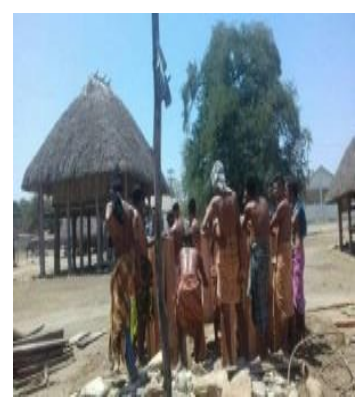

Gambar 3. Proses pergantiaan Xadan yang lama Sumber : Tanya 2019

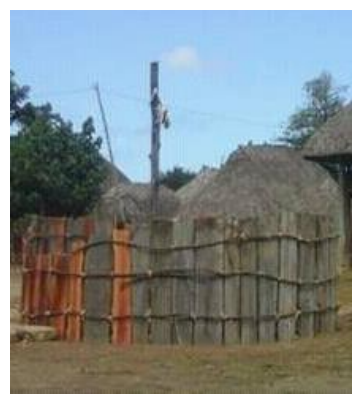

Gambar 4. Xadan yang sudah selesai di ganti Sumber : Tanya 2019

Setelah pergantian Xadan selesai maka upacara puncak akan segera dimulai. Dalam upacara puncak ini para lelaki yang akan mengikuti upacara akan di wajibkan untuk membawakan ayam jantan satu ekor perorang sebagai syarat atau symbol untuk mendapat 
ilmu kekuatan atau ilmu kekebalan tubuh dari para leluhur.Ayam yang dibawa oleh lelaki akan di ritualkan oleh kepala suku selaku perantara antara leluhur dengan orang yang meningikan ilmu kekebalan tubuh.Setelah ayam di mantrakan oleh kepala suku, lalu ayam akan segera dipotong atau sembelih di tempat yang telah di tentukan terlebih dahulu. Setelah ayam di sembelih ayam akan di bakar untuk memmberikan bulunya setelah ayamnya di bersihkan dan akan di potong-potong sebanyak atau sejumlah lelaki yang akan menerima kekebalan tubuh

Ayam yang sudah di potong, segera dimasak untuk ritualkan bagi para leluhur setelah ayam dimasak, maka ayam yang telah di masak mulailah di taru di wadah atau tempat yang telah di persiapkan terlebih dahulu setelah persiapan selesai maka akan di sajikan pada lingkaran Xadan yang telah di persiapkan terlebih dahulu sebelum upacara di mulai.Sebelum para leluhur makan dan minum ayam yang sudah di masak tidak boleh makan duluan para lelaki yang ingin mendapatkan kekebalan tubuh, biarkan para leluhur makan duluan dan minum selang beberapa menit kemudian baru para lelaki mulai makan ,tidak boleh menyisakan daging ditempat Xadan harus habis.

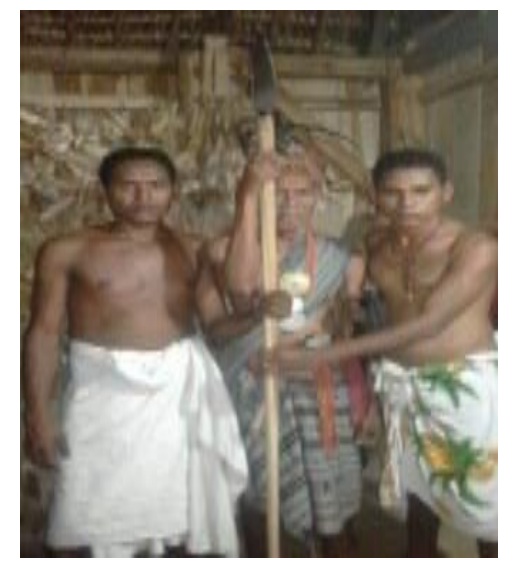

Gambar 5. Para Lelaki yang akan mengikuti ritual kekebalan tubuh Sumber: Tanya 2019

Setelah persembahan berupa sesejajiaan selesai untuk para leluhur atau nenek moyang selesai, maka masuklah setiap para lelaki kedalam Xadan yang telah di perbeharui untuk menyantap makanan atau sesajian yang dipersembahan atau yang telah di upacarain oleh kepala suku sebagai tanda bahwa para lelaki yang ikut memakan sesajian bahwa sudah sah atau sudah di restui oleh para leluhur untuk mendapatkan atau memperoleh ilmu kekebalan tubuh. Sesudah selesai makan-makan maka berakhir pula proses ritual pergantian Xadan.

\section{PENUTUP}

\section{Simpulan}

Xadan merupakan tempat sakral bagi masyarakat Suku Suhi karena mengandung unsur nilainilai spiritual yang sangat tinggi.Masyarakat suku Suhi sangat menghormati para leluhurnya sehingga selalu melaksanakan ritual-ritual sebagai bukti perwujutan sikap menghormati bagi para leluhurnya. Xadan merupakan tempat sesajian bagi para leluhur yang di pakai sewaktuwaktu pada saat upacara untuk mendapatkan ilmu kekebalan tubuh. 


\section{Saran}

Ditujukan kepada generasi suku Suhi agar tetap menjaga dan meletasrikan Xadan sebagai aset budaya setempat karena aset peninggalan dari para leluhur suku suhi

\section{Ucapan Terima Kasih}

Sumber kesaksian dari masyarakat suku suhi,yaitu Ibu Margaretha, Bei Iku Fahik (selaku kepala suku Uma Lulik) Alexander Seran, Ani Mali, dan lain - lainnya yang tidak dapat saya sebutkan satu persatu.

\section{DAFTAR PUSTAKA}

Sugiyono. 2014. Penelitian Kualitatif Berlandaskan Pada Realitas atau Fakta dari GejalaGejala yang Ada Dilapangan.

Usman. 2014. Wawancara merupakan tanya jawab lisan antara dua orang atau lebih secara langsung 